\title{
The Mapping of Geography Courses at Universiti Pendidikan Sultan Idris with a Standard Curriculum for Secondary School in Malaysia
}

\section{Pemetaan Kursus Geografi di Universiti Pendidikan Sultan Idris dengan Kurikulum Standard Sekolah Menengah di Malaysia}

\author{
Mohmadisa Hashim, Hanifah Mahat, Nasir Nayan, Yazid Saleh, Koh Liew See
}

Jabatan Geografi \& Alam Sekitar, Fakulti Sains Kemanusiaan, Universiti Pendidikan Sultan Idris, 35900 Tanjong Malim, Perak

*Corresponding author: mohmadisa@fsk.upsi.edu.my

Article history: Received 31 January 2019 Received in revised form: 14 April 2019 Accepted: 07 May 2019 Published online: 31 August 2019

\begin{abstract}
The purpose of this article is to map the curriculum of Bachelor of Education in Geography programme with the Standard Document of Curriculum and Assessment (DSKP) in school. An analysis of document been implemented to examine the linkages between the geography curriculum at Universiti Pendidikan Sultan Idris (UPSI) towards the geography subject in Standard Curriculum for Secondary School (KSSM) of form one, two and three. The relationship matrix of paralleled themes was identified with the ATLAS.ti software. The themes examined comprised of physical geography, human geography and geographic skills. The results showed that 14 out of 16 courses of BED Geography were parallel with the Geography DSKP for form 1 to 3 . There were eight topics in the DSKP of KSSM Geography that were not related in any Geography BED Instructional Plan, which involved two form 1 topics, titled Kedudukan and Lakaran Peta Malaysia; three form 2 topics, namely Telekomunikasi di Malaysia, Jenis dan Kemajuan Pengangkutan di Asia and Teknologi Hijau; and three form 3 topics, namely Tumbuh-Tumbuhan Semula Jadi di Malaysia, Hidupan Liar di Malaysia and Kitar Semula. The results showed that the university department need to improve the existing courses and there was a need for an addition of relevant courses to the Geography BED programme to aligned with the latest school curriculum. The findings of this study will be able to improve the education system at the university level in order to produce prospective geography teachers with the latest knowledge and the 21 st century skills.
\end{abstract}

Keywords: Kurikulum Standard Sekolah Menengah; Standard Document for Curriculum and Assessment; Geography Education; Curriculum

\begin{abstract}
Abstrak
Tujuan artikel ini ialah membuat pemetaan kurikulum Ijazah Sarjana Muda Pendidikan (ISMP) Geografi dengan Dokumen Standard Kurikulum dan Pentaksiran (DSKP) Geografi di sekolah. Kaedah analisis dokumen telah dilakukan terhadap kurikulum geografi di Universiti Pendidikan Sultan Idris (UPSI) bersama dengan Kurikulum Standard Sekolah Menengah (KSSM) bagi mata pelajaran geografi tingkatan satu hingga tiga. Matriks hubungan bagi tema yang selari dikenal pasti dengan menggunakan perisian ATLAS.ti. Tema yang diteliti terdiri daripada geografi fizikal, geografi manusia dan kemahiran geografi. Hasil analisis mendapati sebanyak 14 kursus daripada 16 kursus ISMP Geografi ialah selaras dengan DSKP Geografi KSSM tingkatan 1 hingga 3. Terdapat lapan topik DSKP Geografi KSSM tiada hubungan dengan Rancangan Instruksional ISMP Geografi iaitu, dua topik adalah daripada tingkatan 1 iaitu di bawah tajuk Kedudukan dan Lakaran Peta Malaysia; tiga topik daripada tingkatan 2 iaitu Telekomunikasi di Malaysia, Jenis dan Kemajuan Pengangkutan di Asia serta Teknologi Hijau; dan tiga topik daripada tingkatan 3 iaitu Tumbuh-Tumbuhan Semula Jadi di Malaysia, Hidupan Liar di Malaysia dan Kitar Semula. Hasil daripada dapatan kajian ini menunjukkan bahawa pihak jabatan perlu melakukan penambahbaikan terhadap kursus sedia ada dan perlu ada penambahan kursus yang relevan dalam ISMP Geografi agar selaras dengan kurikulum sekolah terkini. Penemuan kajian ini mampu memperbaiki sistem pendidikan di peringkat universiti supaya dapat melahirkan bakal guru geografi yang berilmu pengetahuan terkini dan mempunyai kemahiran abad ke-21.
\end{abstract}

Kata kunci: Kurikulum Standard Sekolah Menengah; Dokumen Standard Kurikulum dan Pentaksiran; Pendidikan Geografi; Kurikulum

(C) 2019 Penerbit UTM Press. All rights reserved

\subsection{PENGENALAN}

Kurikulum merupakan perkara penting dalam menyampaikan sesuatu ilmu dalam mana-mana institusi pendidikan. Ilmu yang disampaikan oleh guru dengan pelbagai kaedah pengajaran agar apa yang disampaikan dapat diterima oleh pelajar. Kurikulum yang disampaikan oleh guru juga tidak statik dan ia mengalami perubahan dari semasa ke semasa akibat daripada keperluan negara untuk mencapai sebuah negara 
maju dan mampu berdaya saing di pentas dunia. Menurut Nor Fauzian dan Fauziah Hanim (2015), pembentukan dan perubahan kurikulum adalah juga disebabkan oleh kehendak dan keperluan murid, negara dan kehendak sejagat. Perubahan ini telah menyebabkan kurikulum mata pelajaran yang diajarkan di sekolah turut mengalami reformasi termasuk mata pelajaran geografi. Seiring dengan perubahan pada kurikulum tersebut, maka semakan semula kursus yang ditawarkan di peringkat universiti perlu juga dilakukan (Mohamad Suhaily Yusri \& Mohmadisa, 2013). Hal ini supaya penawaran kursus seiring dengan keperluan kurikulum terkini terutamanya di universiti awam yang menawarkan program pendidikan seperti Universiti Pendidikan Sultan Idris (UPSI), Malaysia supaya selaras dengan kurikulum sekolah terkini.

UPSI merupakan sebuah institusi pendidikan kebangsaan yang menyediakan tenaga profesional dalam bidang keguruan dan menyediakan guru-guru yang berkualiti bagi melahirkan pelajar-pelajar yang cemerlang dalam usaha memajukan sistem pendidikan negara (Mohd Mustamam et al., 2010). Selain itu, Merfat Ayesh (2016) menegaskan bahawa pendidik merupakan watak utama dalam proses pelaksanaan kurikulum kerana pendidik paling berpengetahuan tentang amalan mengajar dan bertanggungjawab memperkenalkan kurikulum di dalam bilik darjah. Memandangkan kurikulum geografi di sekolah mengalami perubahan pada masa kini, maka penawaran kursus-kursus sedia ada dalam program Ijazah Sarjana Muda Pendidikan (ISMP) Geografi di Jabatan Geografi dan Alam Sekitar, Fakulti Sains Kemanusiaan (FSK), UPSI perlu disemak semula supaya relevan dan sesuai dengan kurikulum yang diguna pakai di peringkat sekolah pada masa kini. Hal ini kerana program ISMP Geografi ditawarkan kepada bakal pendidik yang akan mengajar mata pelajaran geografi di sekolah. Justeru, bakal guru geografi perlu menguasai isi kandungan terkini selaras dengan fokus Dokumen Standard Kurikulum dan Pentaksiran (DSKP) Geografi. Justeru kajian ini bertujuan untuk meneliti dalam bentuk matrik perbandingan antara kurikulum ISMP Geografi UPSI dengan DSKP geografi di sekolah khususnya bagi tingkatan 1, 2 dan 3.

\subsection{SOROTAN KAJIAN}

\section{Konsep Kurikulum dan Geografi}

Kurikulum berasal daripada bahasa Latin iaitu "curriculum" yang terdiri daripada dua makna iaitu i) berlari, lumba atau kursus dan ii) kursus perlumbaan (race-course) atau kerjaya (Connelly \& Lantz, 1991; Egan, 2003; Djuwairiah, 2014). Menurut Nor Fauzian dan Fauziah Hanim (2015), kurikulum merupakan dokumen penulisan yang dirancang untuk pembelajaran dan mengandungi senarai topik pembelajaran yang akan dilaksanakan oleh pendidik. Dalam konteks Malaysia, kurikulum merujuk kepada segala rancangan pendidikan untuk mencapai matlamat pendidikan negara seperti mana yang digariskan dalam Falsafah Pendidikan Kebangsaan dan diselia oleh sesebuah institusi pendidikan iaitu Kementerian Pendidikan Malaysia (KPM) (Jamil \& Norlia, 2008). Namun, kurikulum adalah bersifat dinamik (Soon Singh, 2013) iaitu ia akan berubah mengikut perkembangan semasa. Dengan itu, semakan perlu dilakukan sekurang-kurang lima tahun sekali supaya sistem pendidikan di Malaysia sentiasa dapat dikemas kini. Dalam pelaksanaan kurikulum di sekolah, guru merupakan insan yang perlu memainkan peranan penting dalam memastikan murid dapat menguasai ilmu pengetahuan.

Secara umumnya, geografi pula adalah satu disiplin ilmu berkaitan dengan alam sekeliling yang menjelaskan segala bentuk hidupan dan bukan hidupan yang wujud di sekeliling manusia. Perkataan geografi berasal daripada perkataan Yunani iaitu 'geo' yang membawa maksud bumi dan 'graphien' membawa maksud menulis atau dengan perkataan lain adalah menghuraikan/ menjelaskan/ menggambarkan tentang bumi (earth description) (Mohamad Suhaily Yusri, 2002). Disiplin ilmu ini terbahagi kepada dua sub-disiplin utama iaitu geografi fizikal dan geografi manusia. Dalam konteks kurikulum, fokus pendidikan geografi adalah untuk memahami hubungan antara isu-isu alam sekitar dengan masyarakat serta kesannya terhadap kehidupan seharian masyarakat. Oleh itu, pendidikan geografi penting dalam memahamkan pelajar cara untuk memperoleh pengetahuan dan mempersiapkan diri mereka untuk menganalisis dan memahami masalah dunia yang kompleks dan relevan dalam pelbagai hubungan (Esteves, 2012).

\section{Kurikulum Geografi di Sekolah}

Mata pelajaran geografi atau dahulunya dikenali dengan ilmu alam telah diperkenalkan di peringkat sekolah rendah di Tanah Melayu satu ketika dahulu iaitu pada tahun 1927 dan lebih memberi penekanan terhadap melukis peta daripada ingatan, menghafal nama-nama tempat dan ciri-ciri sesuatu kawasan (Voon, 1990; Abdul Hamid et al., 2006). Mata pelajaran ini turut diajar di sekolah menengah dan kurikulum geografi telah diselaraskan dan perubahan terhadap kurikulum geografi telah dilakukan pada tahun 1956 yang dikatakan seragam untuk semua jenis sekolah sama ada di sekolah rendah dan menengah (Abdul Hamid et al., 2006). Mulai tahun 1968, kurikulum geografi telah ditukar kepada Sukatan Pelajaran Sekolah Menengah (Perantaraan Bahasa Melayu): Ilmu Alam dan kemudiannya, usaha-usaha pengubahsuaian pada kurikulum geografi dijalankan pada tahun 1970 (Khatijah, 1983). Seterusnya, pada tahun 1989, Kurikulum Bersepadu Sekolah Menengah (KBSM) mula dilaksanakan sepenuhnya dan satu sukatan pelajaran khusus dan terperinci telah diperkenalkan iaitu Sukatan Pelajaran Geografi KBSM 1988. Kemudian, proses semakan semula dilakukan sehingga wujud Sukatan Pelajaran Geografi KBSM 2000 yang digunakan sehingga tahun 2016. Kini, sekali lagi kurikulum baharu diperkenalkan iaitu Kurikulum Standard Sekolah Menengah (KSSM) untuk menggantikan KBSM.

KSSM telah mula dilaksanakan secara berperingkat bermula dengan Tingkatan 1 pada tahun 2017 bagi memenuhi keperluan dasar baru di bawah Pelan Pembangunan Pendidikan Malaysia (PPPM) 2013-2025 supaya kualiti kurikulum setanding dan mencapai standard antarabangsa. Menurut Mohamad Fadzil dan Abdul Jaleel (2013), transformasi pendidikan menengah melalui PPPM 2013-2025 menunjukkan kerajaan peka dan prihatin dengan perkembangan sistem pendidikan sedia ada. Kurikulum berasaskan standard ini telah dijelmakan dalam KSSM melalui penggubalan Dokumen Standard Kurikulum dan Pentaksiran (DSKP) yang mengandungi beberapa standard iaitu Standard Kandungan (SK), Standard Pembelajaran (SP) dan Standard Prestasi (SPi) bagi semua mata pelajaran (Bahagian Pembangunan Kurikulum, 2015). Di peringkat menengah rendah, fokus KSSM Geografi adalah penguasaan ilmu tentang bentuk dan ciri reruang serta persekitaran untuk melahirkan murid bersikap positif terhadap alam sekitar. Bagi mencapai fokus KSSM Geografi, pelajar perlu menguasai lima aspek iaitu kemahiran geografi, geografi fizikal, geografi manusia, geografi kawasan serta isu dan pengurusan alam sekitar. 


\section{Perubahan Penawaran Kursus Geografi di UPSI}

Memandangkan kurikulum mata pelajaran Geografi kini bagi Tingkatan 1, 2 dan 3 mengalami pembaharuan dari segi kandungan, pedagogi dan pentaksiran, maka semakan kurikulum ISMP Geografi adalah diperlukan bagi melahirkan guru geografi yang mempunyai ilmu pengetahuan dan memenuhi keperluan kurikulum terkini. Penawaran kursus geografi di UPSI terbahagi kepada tiga tema utama iaitu Geografi Fizikal, Geografi Manusia dan kemahiran geografi. Dalam Geografi Fizikal terdiri daripada enam kursus iaitu HGF3013 Pengantar Persekitaran Fizikal, HGF3023 Kajian Sumber Alam dan Alam Sekitar, HGF3033 Prinsip-Prinsip Geomorfologi, HGF3043 Kajiklim, HGF3053 Biogeografi, dan HGF3063 Kajian Hidrologi Tropikal. Manakala dalam Geografi Manusia pula terdiri daripada enam kursus iaitu HGM3013 Pengantar Persekitaran Manusia, HGM3023 Geografi Ekonomi dan Pembangunan, HGM3033 Geografi Penduduk, HGM3043 Geografi Bandar dan Metropolitan, HGM3053 Geografi Wilayah Asia Monsun dan HGM3063 Geografi Malaysia. Dalam kemahiran geografi pula meliputi lima kursus iaitu HGR3013 Teknik-Teknik dan Kaedah Kuantitatif Dalam Geografi, HGR3023 Metodologi Penyelidikan Dalam Geografi, HGG3013 Sistem Maklumat Geografi dan HGG3023 Aplikasi Sistem Maklumat Geografi dan Analisis Ruangan serta satu kursus adalah keperluan universiti iaitu Projek Penyelidikan/Projek Tahun Akhir. Kursus-kursus tersebut perlu diselesaikan selama lapan semester dengan jumlah 54 jam kredit termasuk 80 jam kredit kursus universiti dan profesional pendidikan. Berdasarkan kajian yang pernah dilakukan oleh Mohd Mustamam et al. (2010) mengenai kesesuaian program pengajian UPSI dengan bidang pekerjaan iaitu keguruan mendapati 100 peratus graduan geografi menyatakan kandungan yang dipelajari memenuhi keperluan pengajaran di sekolah.

Selain itu, kursus tersebut turut ditawarkan kepada pelajar daripada program lain sebagai kursus minor sejumlah 24 jam kredit. Antara kursus yang ditawarkan adalah HGF3013 Pengantar Persekitaran Fizikal, HGM3013 Pengantar Persekitaran Manusia, HGR3013 Teknik-Teknik \& Kaedah Kuantitatif Dalam Geografi, HGF3023 Kajian Sumber Alam \& Alam Sekitar, HGM3033 Geografi Penduduk, HGF3043 Kajiklim, HGM3043 Geografi Bandar dan Metropolitan dan HGM3063 Geografi Malaysia. Berdasarkan kajian yang dijalankan oleh Mohmadisa (2013) mengenai kecenderungan pelajar program lain memilih geografi sebagai program minor di UPSI menunjukkan pelajar memberi sikap yang positif dalam memberi penilaian dan persetujuan yang tinggi terhadap penawaran kursus-kursus yang terdapat di Jabatan Geografi. Hal ini kerana responden beranggapan bidang geografi merupakan satu bidang yang penting dan masih diperlukan dalam arus pendidikan negara masa kini.

\subsection{METODOLOGI}

Kajian ini telah dilaksanakan di Universiti Pendidikan Sultan Idris (UPSI) di Tanjong Malim, Perak, Malaysia. Dalam konteks kajian ini, penelitian kandungan dokumen kurikulum bagi kesemua kursus Program ISMP Geografi yang ditawarkan oleh Jabatan Geografi dan Alam Sekitar di bawah Fakulti Sains Kemanusiaan (FSK). Kajian ini merupakan analisis dokumen yang menggunakan pendekatan kualitatif. Kajian ini hanya melibatkan penggunaan data sekunder iaitu data yang dikumpul daripada sumber yang tersedia (Fauzi, Jamal, \& Mohd Saifoul, 2014). Dengan menggunakan analisis dokumentasi, dua sumber data sekunder utama telah dianalisis maklumatnya iaitu Rancangan Instruksional (RI) kursus dalam ISMP Geografi UPSI dan DSKP Geografi KSSM bagi Tingkatan 1, 2 dan 3. Dalam kajian ini hanya melibatkan sebanyak 16 RI kursus yang diperoleh daripada pihak Jabatan Geografi dan Alam Sekitar, FSK, UPSI, manakala kursus projek penyelidikan/projek tahun akhir tidak diambil kira kerana kursus tersebut adalah kursus keperluan universiti. DSKP Geografi KSSM bagi Tingkatan 1, 2 dan 3 pula diperoleh daripada Bahagian Pembangunan Kurikulum, KPM.

Teknik analisis yang digunakan dalam kajian ini adalah analisis dokumen untuk membandingkan kurikulum ISMP Geografi UPSI dengan DSKP Geografi KSSM di sekolah. Analisis ini merupakan alat saintifik yang melibatkan prosedur khusus bertujuan menyediakan pandangan baharu, meningkatkan kefahaman pengkaji berkaitan fenomena tertentu atau menjelaskan tindakan yang praktikal (Ford, 2004). Analisis dokumen merupakan prosedur yang sistematik untuk mengkaji semula atau menilai dokumen-dokumen yang dicetak atau dokumen elektronik seperti bahan berasaskan komputer dan internet (Bowen, 2009). Analisis ini dilakukan dengan menggunakan perisian ATLAS.ti versi 8. ATLAS.ti merupakan perisian yang berkesan untuk menganalisis data kualitatif, terutamanya untuk sebahagian besar teks, data visual dan audio (Smit, 2002). Di samping itu, ATLAS.ti juga dapat membantu dalam mengorganisasikan data, memberikan kod dan menganalisis data penyelidikan secara efisien dan berstruktur (Afriansyah, 2016). Dengan menggunakan ATLAS.ti, analisis dokumen telah dilakukan melalui proses pengekodan, kategori dan model visual yang berbentuk rangkaian. Dengan itu, setiap kursus telah dipecahkan kepada kod masing-masing. Sementara itu, tema yang dibentuk dalam analisis dokumen terdiri daripada kemahiran geografi, geografi fizikal, geografi manusia, geografi kawasan serta isu dan pengurusan alam sekitar. Kelima-lima tema yang ditetapkan adalah berdasarkan kepada DSKP Geografi KSSM dan RI kursus ISMP Geografi.

\subsection{DAPATAN KAJIAN DAN PERBINCANGAN}

Hasil analisis dokumen mendapati sebanyak 14 daripada 16 kursus ISMP Geografi mempunyai hubungan matrik dengan DSKP Geografi KSSM tingkatan 1 hingga 3 yang dapat dilihat melalui Rajah 1. Didapati lima kursus ISMP Geografi mempunyai hubungan matrik dengan DSKP Geografi KSSM bagi tingkatan 1 hingga 3 iaitu kursus Pengantar Persekitaran Fizikal; Kajian Sumber Alam dan Alam Sekitar; Geografi Malaysia; Teknik-Teknik dan Kaedah Kuantitatif Dalam Geografi; dan Metodologi Penyelidikan Dalam Geografi. Sementara itu, kursus Pengantar Persekitaran Manusia mempunyai hubungan matrik dengan DSKP Geografi KSSM bagi tingkatan 1 dan 3. Bagi kursus ISMP Geografi yang mempunyai hubungan matrik dengan DSKP Geografi KSSM tingkatan 1 ialah kursus Prinsip-Prinsip Geomorfologi; Kajian Hidrologi Tropika; Geografi Penduduk; Geografi Bandar dan Metropolitan; dan Regional Geography of Monsoon Asia. Kursus Kajiklim pula dengan tingkatan 2 dan kursus Biogeografi serta Geografi Ekonomi dan Pembangunan dengan tingkatan 3. Dua kurus ISMP Geografi yang tidak mempunyai hubungan matrik dengan DSKP Geografi KSSM ialah Geographical Information System dan Aplikasi Sistem Maklumat Geografi dan Analisis Ruangan. Tegas Mohd Mustamam et al. (2010), sesuatu program dan silibus yang ditawarkan mestilah memenuhi keperluan semasa agar ia seiring dengan matlamat negara yang mahu melahirkan golongan cendekiawan yang ramai dan berkualiti. Dalam penulisan Mohd Zailani dan Mohamad Khairi (2018) turut menyatakan bahawa tahap kesesuaian kandungan 
kurikulum yang tinggi sekali gus mampu memberi impak positif kepada bakal guru dalam penyediaan diri menjadi seorang guru baharu yang cemerlang serta bersedia menggalas tanggungjawab sebagai ejen transformasi pendidikan negara.

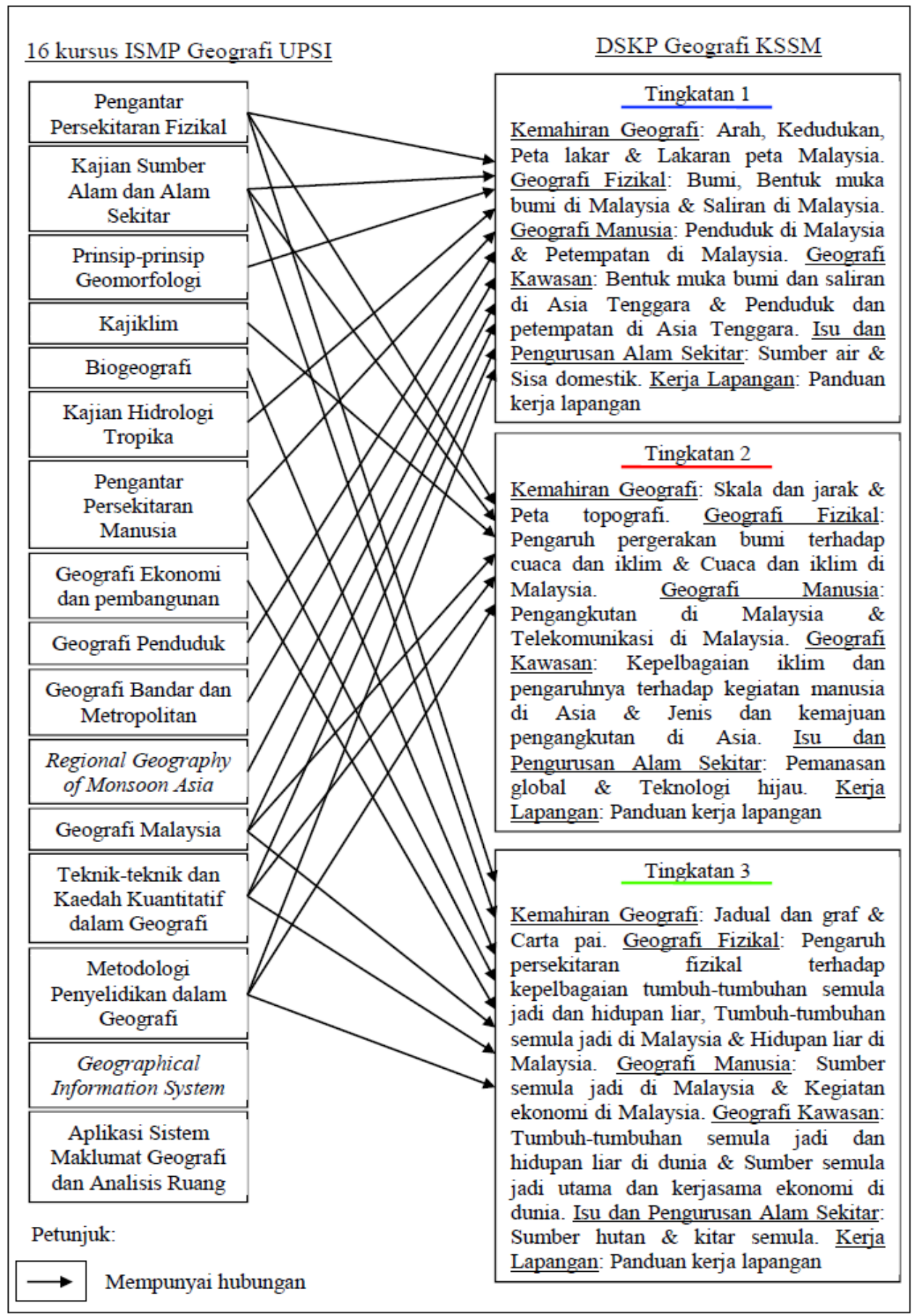

Rajah 1 Hubungan matrik antara kursus-kursus ISMP Geografi UPSI dengan DSKP Geografi KSSM Tingkatan 1 hingga 3

Hasil analisis dokumen juga mendapati kursus-kursus dalam bidang Geografi Fizikal iaitu Pengantar Persekitaran Fizikal menepati beberapa topik dalam DSKP Tingkatan 1 hingga 3 iaitu topik Bumi dan Sumber Air dalam DSKP Tingkatan 1, topik Pengaruh Pergerakan Bumi Terhadap Cuaca dan Iklim serta Pemanasan Global dalam DSKP Tingkatan 2 dan topik Pengaruh Persekitaran Fizikal Terhadap Kepelbagaian Tumbuh-Tumbuhan Semula Jadi dan Hidupan Liar dalam DKSP Tingkatan 3 (Rajah 2). Bagi kursus Kajian Sumber Alam dan Alam Sekitar pula, terdapat beberapa topik adalah menepati DSKP Tingkatan 1, 2 dan 3 iaitu topik Sumber Air dan Sisa Domestik dalam DSKP Tingkatan 1, topik Pemanasan Global dalam DSKP Tingkatan 2 dan topik Sumber Hutan dalam DSKP Tingkatan 3 (Rajah 3). 


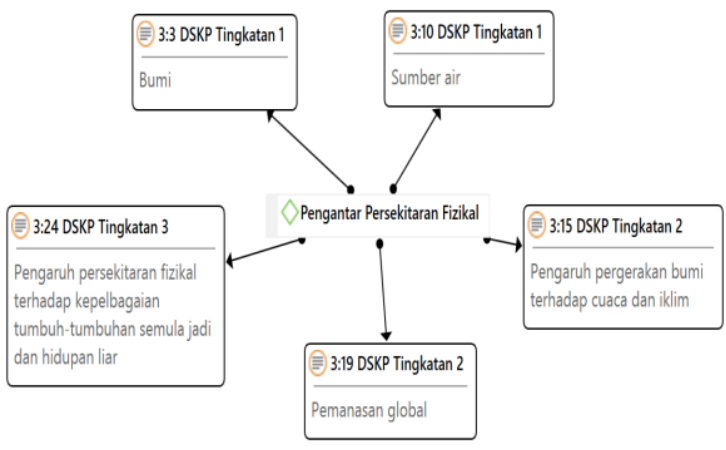

Rajah 2 Kaitan kursus Pengantar Persekitaran Fizikal dan DSKP Geografi KSSM

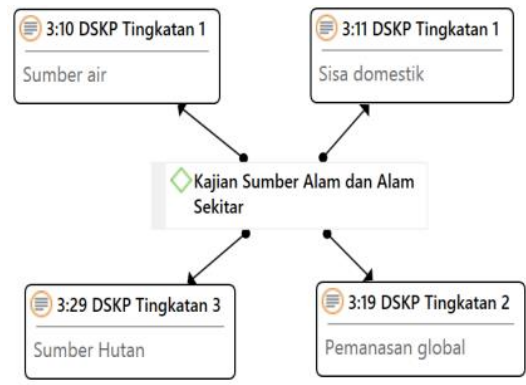

Rajah 3 Kaitan kursus Kajian Sumber Alam \& Alam Sekitar dan DSKP Geografi KSSM

Kursus Prinsip-Prinsip Geomorfologi pula hanya menepati satu topik dalam DSKP Tingkatan 1 iaitu Bumi yang meliputi Sistem Fizikal Bumi, Struktur Bumi, Benua dan Lautan serta Kesan Pergerakan Kerak Bumi (Rajah 4). Hasil analisis dokumen juga mendapati kursus Kajiklim hanya menepati topik dalam DSKP Tingkatan 2 iaitu Pengaruh Pergerakan Bumi Terhadap Cuaca dan Iklim, Cuaca dan Iklim di Malaysia, Kepelbagaian Iklim dan Pengaruhnya Terhadap Kegiatan Manusia di Asia dan Pemanasan Global (Rajah 5). Di samping itu, kursus Biogeografi pula menepati dua topik dalam DSKP Tingkatan 3 iaitu Pengaruh Persekitaran Fizikal Terhadap Kepelbagaian Tumbuh-Tumbuhan Semula Jadi dan Hidupan Liar dan Tumbuh-Tumbuhan Semula Jadi dan Hidupan Liar di Dunia (Rajah 6). Kursus Kajian Hidrologi Tropika pula hanya menepati DSKP Tingkatan 1 iaitu topik Saliran di Malaysia dan Sumber Air (Rajah 7).

Prinsip-prinsip Geomorfologi

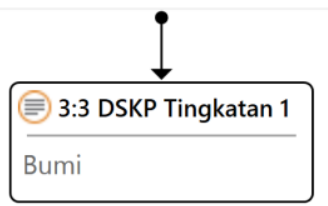

Rajah 4 Kaitan kursus Prinsip-Prinsip Geomorfologi dan DSKP Geografi KSSM

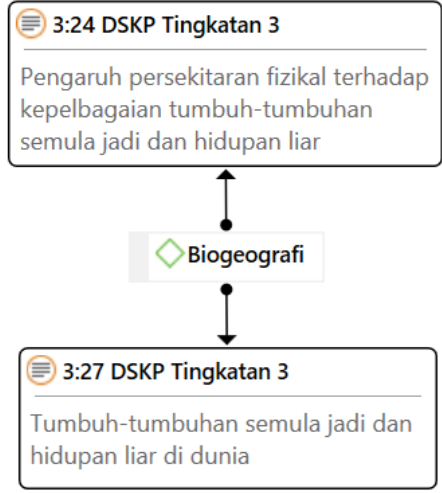

Rajah 6 Kaitan kursus Biogeografi dan DSKP Geografi KSSM

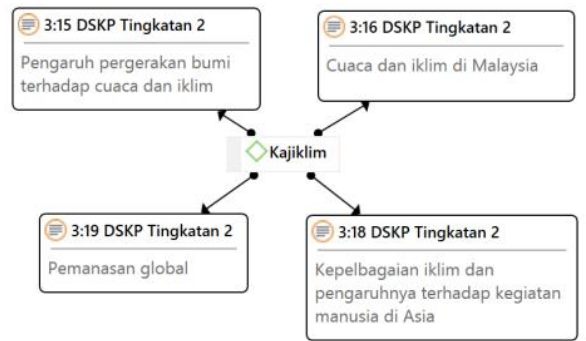

Rajah 5 Kaitan kursus Kajiklim dan DSKP Geografi KSSM

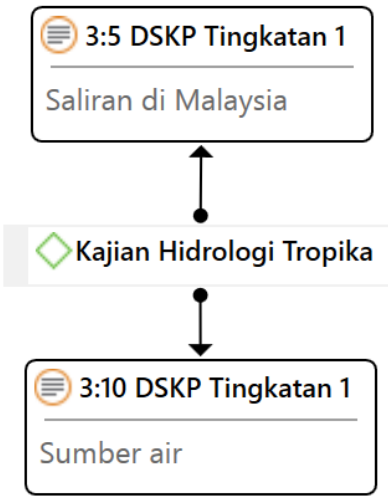

Rajah 7 Kaitan kursus Kajian Hidrologi Tropika dan Geografi KSSM Geografi

Seterusnya, bagi kursus-kursus dalam bidang Geografi Manusia iaitu Pengantar Persekitaran Manusia menepati dua topik DSKP Tingkatan 1 iaitu Penduduk di Malaysia dan Petempatan di Malaysia dan satu topik DSKP Tingkatan 3 iaitu Kegiatan Ekonomi di Malaysia (Rajah 8). Kursus Geografi Ekonomi dan Pembangunan pula hanya menepati dua topik dalam DSKP Tingkatan 3 iaitu Kegiatan Ekonomi di Malaysia dan Sumber Semula Jadi Utama dan Kerjasama Ekonomi di Dunia (Rajah 9). Begitu juga dengan kursus Geografi Penduduk hanya menepati dua topik DSKP Tingkatan 1 iaitu Penduduk di Malaysia serta Penduduk dan Petempatan di Asia Tenggara (Rajah 10). Kursus Geografi Bandar dan Metropolitan pula hanya menepati satu topik DSKP Tingkatan 1 iaitu Petempatan di Malaysia (Rajah 11). Bagi kursus Geografi Wilayah Asia Monsun hanya menepati dua topik DSKP Tingkatan 1 iaitu Bentuk Muka Bumi dan Saliran di Asia Tenggara dan Penduduk dan Petempatan di Asia Tenggara (Rajah 12). Selain itu, hasil analisis dokumen mendapati kursus Geografi Malaysia menepati beberapa tajuk dalam DSKP Tingkatan 1 hingga 3 iaitu topik Penduduk di Malaysia dan Bentuk Muka Bumi di Malaysia dalam DSKP Tingkatan 1, topik Cuaca dan Iklim di Malaysia dan Pengangkutan di Malaysia dalam DSKP Tingkatan 2 dan topik Sumber Semula Jadi di Malaysia, Kegiatan Ekonomi di Malaysia dan Sumber Semula Jadi Utama serta Kerjasama Ekonomi di Dunia dalam DKSP Tingkatan 3 (Rajah 13). 


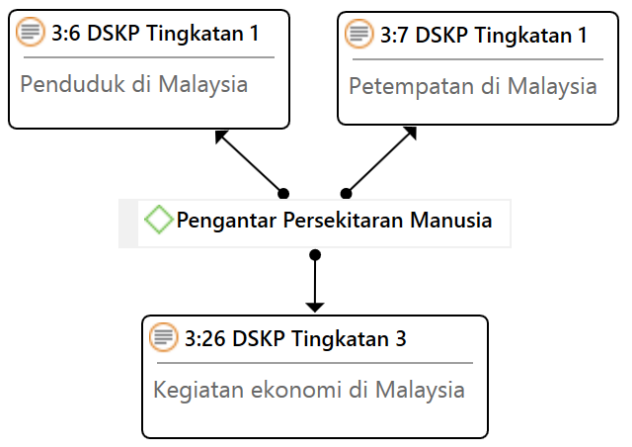

Rajah 8 Kaitan kursus Pengantar Persekitaran Manusia dan DSKP Geografi KSSM

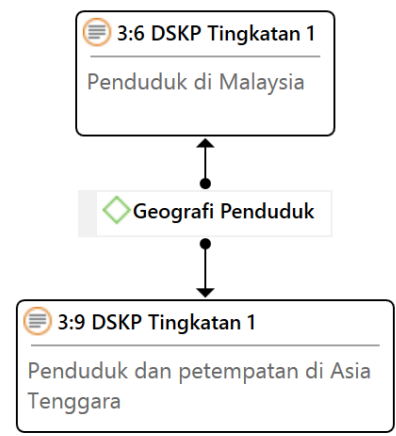

Rajah 10 Kaitan kursus Geografi Penduduk dan DSKP Geografi KSSM

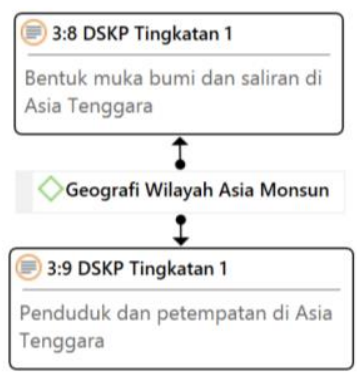

Rajah 12 Kaitan kursus Geografi Wilayah Asia Monsun dan DSKP Geografi KSSM

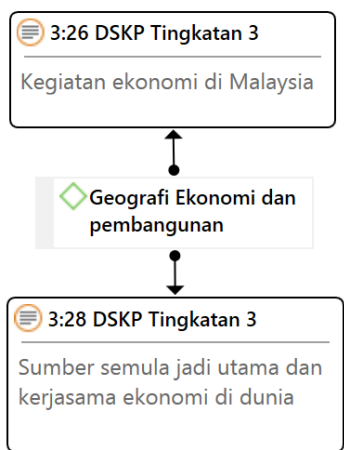

Rajah 9 Kaitan kursus Geografi Ekonomi \& Pembangunan dan DSKP Geografi KSSM

Geografi Bandar dan Metropolitan

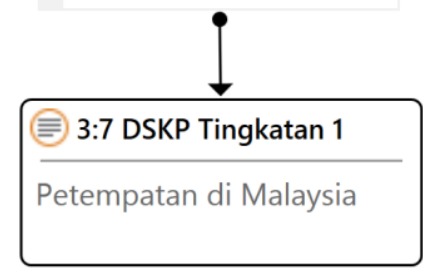

Rajah 11 Kaitan kursus Geografi Bandar \& Metropolitan dan DSKP Geografi KSSM

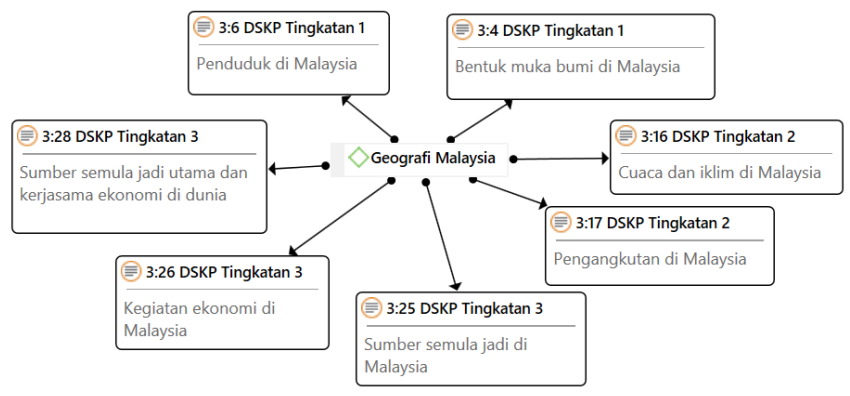

Rajah 13 Kaitan kursus Geografi Malaysia dan DSKP Geografi KSSM

Di samping itu, bagi kursus-kursus dalam bidang kemahiran geografi iaitu kursus Teknik-Teknik dan Kaedah Kuantitatif dalam Geografi pula menepati dua topik dalam DSKP Tingkatan 1 iaitu Arah dan Peta Lakar, dua topik dalam DSKP Tingkatan 2 iaitu Skala dan Jarak serta Peta Topografi dan dua topik dalam DSKP Tingkatan 3 iaitu Jadual dan Graf serta Carta Pai (Rajah 14). Kursus Metodologi Penyelidikan dalam Geografi pula menepati panduan kerja lapangan dalam DSKP Tingkatan 1 hingga 3 (Rajah 15).

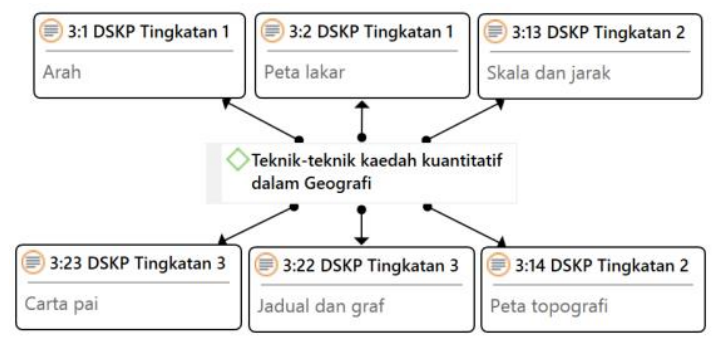

Rajah 14 Kaitan kursus Teknik-Teknik Kaedah Kuantitatif dalam Geografi dan DSKP Geografi KSSM

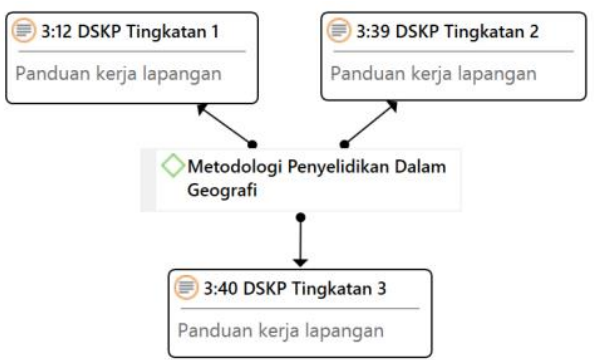

Rajah 15 Kaitan kursus Metodologi Penyelidikan dalam Geografi dan DSKP Geografi KSSM 
Penemuan kajian juga mendapati dua kursus ISMP Geografi tiada hubungan dengan DSKP Geografi KSSM Tingkatan 1 hingga 3 iaitu kursus Sistem Maklumat Geografi (GIS) dan Aplikasi Sistem Maklumat Geografi dan Analisis Ruangan kerana GIS tiada dalam kurikulum pendidikan geografi sekolah. GIS merupakan sistem maklumat yang digunakan untuk menyimpan, memaparkan, menganalisis dan memanipulasi data yang berkaitan dengan ruangan (Soon Singh, 2013). Menurut Acquah, Asamoah, dan Konadu (2017), GIS merupakan perisian atau alat yang berupaya untuk mengintegrasikan kedua-dua data spatial dan data atribut yang diwakili. Antara cabaran Kementerian Pendidikan Malaysia tidak mengintegrasikan GIS dalam pendidikan geografi kerana kekurangan kemahiran dalam kalangan guru dan kemudahan ICT di sekolah (Soon Singh, 2013; Habibah \& Muniandy, 2011; Nordin, 2006). Kekurangan pada kemampuan, sumber manusia dan kemudahan ICT di sekolah akan menyebabkan pelajar tidak dapat menguasai kemahiran GIS dengan baik. Sebaliknya, Kocalar dan Demirkaya (2017) menjelaskan bahawa makmal geografi yang dilengkapi kemudahan, guru yang berkelayakan, penggunaan bahan-bahan pengajaran dan penyertaan aktif pelajar akan meningkatkan kecekapan guru terhadap pengajaran dan memberi pelajar peluang untuk pendidikan yang lebih berkesan dalam geografi.

\subsection{KESIMPULAN}

Semakan terhadap kurikulum sentiasa diperlukan bagi menyediakan pendidikan yang berfokus kepada pembangunan sumber manusia untuk memenuhi keperluan pembangunan sosial, ekonomi dan politik negara. Artikel ini telah menunjukkan bahawa sebahagian besar penawaran kursus ISMP Geografi di UPSI telah memenuhi DSKP Geografi KSSM tingkatan 1 hingga 3 sahaja. Diharapkan pada semakan semula program pengajian pada masa hadapan akan mengambil kira DSKP Geografi KSSM bagi tingkatan 4 dan 5 . Hanya dua kursus sahaja yang tiada hubungan dengan DSKP Geografi KSSM iaitu Geographical Information System dan Aplikasi Sistem Maklumat Geografi dan Analisis Ruangan. Penulisan artikel ini juga telah mendorong kepada pengemaskinian program ISMP Geografi UPSI supaya lebih relevan dan memenuhi DSKP Geografi KSSM Tingkatan 1 hingga 3 bahkan selaras dengan DSKP Geografi KSSM tingkatan 4 dan 5 yang akan dilaksanakan pada tahun 2020 dan 2021. Dengan adanya semakan ini mampu menyediakan bakal guru geografi dengan ilmu pengetahuan yang terkini selaras dengan kurikulum baharu di sekolah. Di samping itu juga dapat meningkatkan kualiti sistem pendidikan di peringkat fakulti dengan melakukan penambahbaikan kursus sedia ada dan penawaran kursus-kurus baru dan menepati kurikulum masa kini.

\section{Penghargaan}

Terima kasih kepada pihak Universiti Pendidikan Sultan Idris (UPSI) melalui Pusat Pengurusan Penyelidikan dan Inovasi (RMIC) yang menyediakan dana Geran Penyelidikan Universiti berteraskan Pendidikan 2018 (Kod Penyelidikan: 2018-0039-107-01) bagi menjalankan penyelidikan berkaitan dengan artikel ini.

\section{Rujukan}

Abdul Hamid, A., Mohmadisa, H., Mohd Faris, D. \& Mohamad Suhaily Yusri, C. N. (2006). Isu-Isu Pendidikan Geografi di Malaysia. Tanjong Malim: Penerbit UPSI.

Acquah, C. P., Asamoah, N. J., \& Konadu, D. D. (2017). Introduction of Geographical Information Systems (GIS) in Technical University Education in Ghana: Challenges and the way forward. Review of International Geographical Education Online (RIGEO), 7(2), 207-220.

Afriansyah, E. A. (2016). Penggunaan Software ATLAS. ti sebagai Alat Bantu Proses Analisis Data Kualitatif. Mosharafa: Jurnal Pendidikan Matematika, 5(2), 5363.

Bahagian Pembangunan Kurikulum. (2015). Dokumen standard kurikulum dan pentaksiran Geografi Tingkatan 3 KSSM. Putrajaya: Bahagian Pembangunan Kurikulum.

Bowen, G. A. (2009). Document analysis as a qualitative research method. Qualitative Research Journal, 9(2), $27-40$.

Connelly, F. M., \& Lantz, O. C. (1991). Definations of curriculum: An introduction. Dalam Lewy, A. (Ed.), The International Encyclopaedia of Curriculum (pp. 1518). New York: Pergamon Press.

Djuwairiah, A. (2014). Understanding the 2013 curriculum of English Teaching Through The Teachers And Policymakers Perspective. International Journal of Enhanced Research in Educational Development, 2(4), 6-15.

Egan, K. (2003). What is curriculum? Journal of the Canadian Association for Curriculum Studies, 1(1), 9-16.

Esteves, M. H. (2012). Geography education and citizenship education in Portugal: A challenge for the 21st century. SAGE Open, 2(4), 1-10.

Fauzi, H., Jamal, A., \& Mohd Saifoul, Z. N. (2014). Kaedah penyelidikan \& analisis data SPSS. Sintok, Kedah: Penerbit Universiti Utara Malaysia.

Ford, J. M. (2004). Content analysis: An introduction to its methodology. Personnel Psychology, 57(4), 1110-1113.

Habibah, L., \& Muniandy, V. (2011). GIS in the Malaysian Geography Education: Challenges And Potentials. Geografia-Malaysian Journal of Society and Space, $7(1), 42-52$.

Jamil, A., \& Norlia, G. (2008). Pentadbiran dan Pengurusan Sistem Pendidikan Malaysia Ke Arah Pendidikan Berkualiti. Panitia Diklat Manajemen Guru Internasional 2008.

Kaya, N. (2018). Main Challenges In Front Of The Teachers To Teach Geography More Effectively: A Phenomenological Research. Review of International Geographical Education Online (RIGEO), 8(2), 371-393.

Khatijah, K. (1983). Kurikulum geografi di sekolah-sekolah menengah. Pendidik dan Pendidikan, 5(1), 54-60.

Kocalar, A. O., \& Demirkaya, H. (2017). Geography Teachers' Views On Effective Geography Teaching. Review of International Geographical Education Online (RIGEO), 7(3), 332-346.

Merfat Ayesh, A. (2016). Curriculum Development: Teacher Involvement In Curriculum Development. Journal of Education and Practice, 7(9), $106-107$.

Mohamad Fadzil, C. A., \& Abdul Jaleel, A. H. (2013). Menilai Keberkesanan Pelaksanaan Program Diploma Perguruan Lepasan Ijazah Pendidikan Pendidikan Sejarah Sekolah Rendah di Institut Pendidikan Guru Kampus Puala Pinang. Dalam Seminar Pendidikan Sejarah dan Geografi, 214-225. Universiti Malaysia Sabah.

Mohamad Suhaily Yusri, C. N. (2002). Pengantar Persekitaran Fizikal. Tanjong Malim: Penerbit Universiti Pendidikan Sultan Idris.

Mohamad Suhaily Yusri, C. N. \& Mohmadisa, H. (2013). Pendidikan geografi di Universiti Pendidikan Sultan Idris: Ke Arah Memartabatkan Disiplin Geografi Dalam Pembangunan Negara. Dlm. Habibah Hj. Lateh, Wan Rozali Wan Hussin, Sibly Maros \& Misni Surif (Ed.), Isu-Isu Semasa Dalam Pendidikan Geografi di Malaysia. Pulau Pinang: Pusat Pengajian Pendidikan Jarak Jauh USM, 67-81. 
Mohd Mustamam, A. K., Zakaria, K., Mohamad, I., Mohd Ramli, B. K., Amir Hasan, D., Ahmad, H., Che Mohd Zuklifli, C.O., Mohamad Suhaily Yusri, C.N., Saberi, O., Adnan, M.N., Haji Iberahim, H., Abdul Kadir, A., Mohd Nazri, M.S, \& Mohammad Sidik, A. (2010). Kajian Penyesuaian Program Pengajian UPSI Dengan Bidang Pekerjaan (Graduan 1999-2009). Laporan Penyelidikan Geran Penyelidikan UPSI yang tidak diterbitkan. Tanjong Malim.

Mohd Zailani, I., \& Mohamad Khairi, O. (2018). Penilaian kesesuaian kurikulum Program Ijazah Sarjana Muda Perguruan (PISMP) pendidikan Islam di Institut Pendidikan Guru Malaysia. Internatinal Journal of Education, Psychology and Counseling, 3(8), 91-106.

Mohmadisa, H. (2013). Kecenderungan Pelajar Universiti Pendidikan Sultan Idris (UPSI) Memilih Minor Geografi. Dalam Habibah, H.L., Wan Rozali, W.H., Sibly, M., \& Misni, S. (Eds.), Isu-Isu Semasa Dalam Pendidikan Geografi Di Malaysia, 29-46. Pulau Pinang: Pusat Pengajian Jarak Jauh, USM.

Nor Fauzian, K., \& Fauziah Hanim, A. J. (2015). Kurikulum Pendidikan Awal Kanak-Kanak Dan Modul Pendidikan Akhlak: Isu Dan Cabaran Masa Kini. Dalam Seminar Penyelidikan Kebangsaan. UPSI, Tanjong Malim.

Nordin, S. (2006). Teaching GIS in Sabah: An Early Survey Towards GIS In Schools In Environmental Geography And Education. Tanjong Malim: Penerbit Universiti Pendidikan Sultan Idris.

Smit, B. (2002). ATLAS.ti for Qualitative Data Analysis. Perspectives in Education, 20(3), 65-75.

Soon Singh, B. S. (2013). Integrating Geography Information System In Teaching Geography In Malaysian Secondary Smart Schools. Education Journal, 2(4), 149154.

Voon, P. K. (1990). Geography Education In Malaysia. Malaysian Journal of Tropical Geography, 21(2), 92-111. 